\title{
Na Vice-Diretoria da Faculdade de Direito, Alexandre Augusto de Castro Correa
}

A 13 de setembro de 1982, por escolha da Congregação, assumiu a Vice-Diretoria da Faculdade de Direito da Universidade de São Paulo o ilustre Professor Doutor Alexandre Augusto de Castro Correa.

Profundo conhecedor de diversos idiomas, francês, inglês, alemão, italiano, latim e grego, o Doutor Alexandre Augusto é o titular da cadeira de Direito Romano, desde 5 de fevereiro de 1965, vaga deixada pelo saudoso Professor Alexandre Correa, seu pai.

$\mathrm{O}$ douto mestre possui extensa bagagem de livros e artigos publicados, além de ter elaborado uma série de tradução de obras em italiano, latim e inglês, de clássicos e renomados autores que se tornaram consulta constante e obrigatória por estudantes e estudiosos do Direito Romano. 